\title{
ANALISIS DAYA SAING EKSPOR UDANG BEKU INDONESIA DI PASAR AMERIKA SERIKAT
}

\author{
Analysis of Indonesian Frozen Shrimp Export Competitiveness \\ in the United States Market
}

\author{
Revan Wahyu Dimantara, Septina Elida \\ Program Studi Agribisnis Universitas Islam Riau \\ Email:revan.wd@gmail.com. \\ [Diterima: Desember 2019; Disetujui: April 2020]
}

\begin{abstract}
The United States is the main market for Indonesia's frozen shrimp exports, after Japan and the European Union. This study aims to analyze: (1) the export performance; (2) the export competitiveness; and (3) the factors affecting export of Indonesian frozen shrimp in the US market. This study uses library research methods, data analysis used in this study are: growth rate, concentration ratio $\left(\mathrm{CR}_{4}\right)$ \& Herfindahl Index (HI); Revealed Comparative Advantage (RCA) \& Constant Market Share Analysis (CMSA); and linear regression with OLS estimation method. The results of the analysis show: (1) The growth of the export value of Indonesian frozen shrimp is $15.54 \%$, while the value of $\mathrm{CR}_{4} \& \mathrm{HI}$ is $63,69 \%$ \& 1.471 , which are indicate that concentration and competition of the market is at moderate level, where Indonesia's market share is $15,21 \%$ (third highest after India and Thailand), (2) Indonesia's average RCA index is 20,11, the CMSA analysis show that the change in actual market share $\left(0,77 \times 10^{-4}\right)$ is largely influenced by the competitiveness effect $(98,74 \%)$, and the rest is influenced by the commodity composition effect $(2,56 \%)$ and market distribution effect $(-1,30 \%)$, (3) Factors that affect the export of Indonesian frozen shrimp in the US market significantly are domestic production, frozen shrimp export prices, processed shrimp export prices, and real exchange rates.
\end{abstract}

Keyword: Competitiveness, Export, Frozen Shrimp, United States, HI, CR ${ }_{4}, \mathrm{RCA}, \mathrm{CMSA}$.

\section{ABSTRAK}

Amerika Serikat adalah pasar utama untuk ekspor udang beku Indonesia, setelah Jepang dan Uni Eropa. Penelitian ini bertujuan untuk menganalisis: (1) kinerja ekspor; (2) daya saing ekspor; dan (3) faktor-faktor yang mempengaruhi ekspor udang beku Indonesia di pasar AS. Penelitian ini menggunakan metode penelitian kepustakaan, analisis data yang digunakan dalam penelitian ini adalah: laju pertumbuhan, rasio konsentrasi (CR4) \& Indeks Herfindahl (HI); Keuntungan Komparatif Terungkap (RCA) \& Analisis Pangsa Pasar Konstan (CMSA); dan regresi linier dengan metode estimasi OLS. Hasil analisis menunjukkan: (1) Pertumbuhan nilai ekspor udang beku Indonesia adalah 15,54\%, sedangkan nilai CR4 \& HI adalah 63,69\% \& 1,471, yang menunjukkan bahwa konsentrasi dan persaingan pasar berada pada tingkat sedang, di mana pangsa pasar Indonesia adalah 15,21\% (tertinggi ketiga setelah India dan Thailand), (2) Indeks RCA rata-rata Indonesia adalah 20,11, analisis CMSA menunjukkan bahwa perubahan dalam pangsa pasar aktual $(0,77 \times 10-4)$ sebagian besar dipengaruhi oleh efek daya saing $(98,74 \%)$, dan sisanya dipengaruhi oleh efek komposisi komoditas (2,56\%) dan efek distribusi pasar (-1,30\%), (3) Faktor-faktor yang mempengaruhi ekspor udang beku Indonesia di pasar AS secara signifikan adalah produksi dalam negeri, harga ekspor udang beku, harga ekspor udang olahan, dan nilai tukar riil.

Kata kunci: Daya Saing, Ekspor, Udang Beku, Amerika Serikat, HI, CR4, RCA, CMSA.

\section{PENDAHULUAN}

$\begin{array}{ll}\text { Udang merupakan komoditas } & \text { hasil perikanan, dimana pada tahun 2014 - } \\ \text { unggulan dalam ekspor hasil perikanan } & \text { 2016 udang mendominasi lebih dari 40\% dari } \\ \text { Indonesia. Menurut BPS (2017), udang } & \text { total ekspor hasil perikanan Indonesia, dengan } \\ \text { menjadi komoditas unggulan dalam ekspor } & \text { nilai ekspor tertinggi berada pada tahun } 2014\end{array}$


yaitu sekitar US\$ 2.140.862 ribu atau sekitar $46,12 \%$. Sedangkan dalam posisinya dalam perdagangan internasional, pada tahun 2016 Indonesia menjadi eksportir udang terbesar di dunia nomor 6 setelah India, Vietnam, Ekuador, China, dan Thailand. Dimana sebagian sebagian besar udang Indonesia diekspor dalam bentuk beku dengan nilai sebesar US\$ 1.286.673 ribu atau 76,94\% dari total ekspor udang (UN Comtrade, 2018).

Amerika Serikat merupakan salah satu negara importir udang terbesar di dunia, selain Jepang dan Uni Eropa. Udang menjadi salah satu seafood terpopuler di negara tersebut, dimana pada tahun 2011 konsumsi udang per kapitanya yaitu sebesar 4,20 pound/tahun, lebih tinggi dibandingkan dengan konsumsi berbagai jenis seafood lainnya seperti salmon dan tuna (National Marine Fisheries Service, 2017). Tingginya konsumsi udang di AS hanya mampu dipenuhi produksi domestik sekitar $12 \%$ saja, sisanya $88 \%$ berasal dari impor, dimana sebagian besar udang diimpor dalam keadaan beku (Juarno, 2012).

Berdasarkan data dari UN Comtrade (2018), pada Tahun 2016 Indonesia menjadi eksportir udang beku terbesar nomor dua setelah India, dengan persentase nilai $20 \%$ (US\$ 850.673 ribu) dari total ekspor dunia ke Amerika Serikat. Negara eksportir besar lainnya yaitu Ekuador, Thailand, Vietnam, dan Meksiko. Bagi Indonesia, Amerika Serikat merupakan negara tujuan ekspor utama komoditas udang beku, hal ini ditunjukkan dari persentase nilai ekspor udang beku ke negara tersebut pada tahun 2016 yang mencapai $66,11 \%$ dari total nilai ekspor udang beku Indonesia.

Amerika Serikat terkenal dengan kebijakan non tarif nya yang sangat ketat dalam hal impor udang, yaitu seperti menetapkan syarat harus memenuhi prinsip GMP yang merupakan pengejawantahan konsep Hazard Analysis Critical Control Point (HACCP), dan berbagai persyaratan teknis lainnya yang dikaitnya dengan isu lingkungan seperti Turtel Excluder Device (TED), Marine Mammal Protection Act (MMPA), dan lain-lain (Aisya, Koeshendrajana, \& Hartono, 2005). Pemenuhan berbagai persyaratan tersebut berimplikasi pada peningkatan biaya yang memberatkan produsen.

Selain dari pada hambatan dalam memasuki pasar Amerika Serikat yang lebih kepada masalah eksternal, masalah internal yang dihadapi para produsen udang yaitu mayoritas tambak udang yang masih dikelola secara tradisional, memiliki produktifitas rendah, serta biaya produksi yang tinggi. Menurut Rosenberry (1996) dalam Juarno (2012), dari 350000 Ha sebanyak 70\% udang tambak di Indonesia dikelola menggunakan teknologi ekstensif, $15 \%$ semi-intensif, dan hanya $15 \%$ yang menggunakan teknologi intensif. Selanjutnya dikatakan bahwa biaya pakan untuk udang di Indonesia relatif lebih mahal 15\% dibandingkan dengan Thailand, dan 40\% lebih mahal dibandingkan China.

Besarnya bagian yang diambil Amerika Serikat dalam ekspor udang beku Indonesia, menjadikan posisi Amerika Serikat sangat vital bagi perdagangan ekspor udang beku Indonesia, yang jika hal ini tidak dapat dipertahankan, maka Indonesia akan kehilangan sebagian besar pasarnya. Berbagai macam kebijakan Amerika Serikat terkait impor udang beku yang ketat, akan berdampak pada semakin sulitnya komoditas udang dari Indonesia untuk dapat bersaing. Penelitian ini bertujuan untuk menganalisis:

1. Kinerja ekspor udang beku Indonesia di pasar Amerika Serikat

2. Daya saing ekspor udang beku Indonesia di pasar Amerika Serikat

3. Faktor-faktor apa saja yang mempengaruhi ekspor udang beku Indonesia di pasar Amerika Serikat.

\section{METODOLOGI PENELITIAN}

Penelitian ini menggunakan metode studi kepustakaan, yang dilaksanakan selama 8 bulan dimulai dari bulan Juni 2018 sampai bulan Januari 2019. Data yang digunakan dalam penelitian ini adalah data sekunder, yaitu data time series (deret waktu) tahunan selama 28 tahun dari tahun 1989 - 2016, yang meliputi data volume, nilai, harga ekspor udang beku (HS 030613) \& olahan (HS 160520), produksi udang domestik, nilai tukar, pendapatan \& konsumsi udang masyarakat Amerika Serikat. Selain daripada data diatas, digunakan pula data-data pendukung lainnya yang bersumber dari beberapa publikasi, literatur \& instansi terkait seperti BPS, Kementrian Perdagangan, Kementrian KKP, dan lain-lain. 
Adapun beberapa metode analisis data yang digunakan dalam penelitian ini adalah sebagai berikut:

\section{Analisis Kinerja Ekspor Udang Beku}

\section{a. Pertumbuhan Ekspor}

Analisis laju pertumbuhan ekspor udang beku dapat dirumuskan sebagai berikut (Susanti, 2010):

$$
g_{t}=\left(\frac{E_{t}-E_{t-1}}{E_{t-1}}\right) \times 100 \%
$$

Keterangan:

$\mathrm{g}=$ Pertumbuhan ekspor udang beku $(\%)$

$\mathrm{E}=$ Nilai ekspor udang beku Indonesia di AS (US\$)

\section{b. Pangsa Pasar}

Pangsa pasar perdagangan udang beku

(HS 030613) Indonesia di pasar Amerika Serikat diukur dengan menggunakan metode Concentration Ratio $\left(\mathrm{CR}_{4}\right)$ dan Herfindahl Index (HI), yang diformulasikan sebagai berikut (Ukav, 2017):

$$
\begin{aligned}
\mathrm{CR}_{4}= & \mathrm{Si}_{1}+\mathrm{Si}_{2}+\mathrm{Si}_{3}+\mathrm{Si}_{4} \ldots \ldots \ldots . . .(2) \\
\mathrm{HI}= & \mathrm{Si}_{1}{ }^{2}+\mathrm{Si}_{2}{ }^{2}+\mathrm{Si}_{3}{ }^{2}+\mathrm{Si}_{4}{ }^{2}+\mathrm{Si}_{5}{ }^{2} \\
& +\mathrm{Si}_{6}{ }^{2}+\ldots . .+\mathrm{S}_{\mathrm{n}}{ }^{2}
\end{aligned}
$$

Sedangkan rumus untuk menghitung pangsa pasar adalah sebagai berikut:

$$
S i_{j}=\frac{X_{i j}}{X_{i}}
$$

Keterangan:

$\mathrm{CR}_{4}=$ Rasio konsentrasi ekspor udang beku oleh 4 negara eksportir utama di pasar Amerika Serikat (\%)

$\mathrm{HI}=$ Herfindahl Index

$\mathrm{S}_{\mathrm{ij}}=$ Pangsa pasar udang beku oleh negara $\mathrm{j}$ ke pasar Amerika Serikat

$\mathrm{X}_{\mathrm{ij}}=$ Ekspor udang beku oleh negara $\mathrm{j}$ ke pasar Amerika Serikat (Ton)

$\mathrm{Xi}=$ Ekspor udang beku oleh dunia ke pasar Amerika Serikat (Ton)

$\mathrm{n}=$ Jumlah seluruh negara eksportir udang beku di Amerika Serikat

Berdasarkan nilai concentration ratio $\left(\mathrm{CR}_{4}\right)$ maka konsentrasi pasar perdagangan udang beku (HS 030613) dapat dikelompokkan sebagai berikut: (1) $80 \%$ $100 \%$, maka tingkat konsentrasi pasar tinggi, dengan bentuk pasar yang memungkinkan adalah monopoli dan oligopoli; (2) $50 \%$ < $\mathrm{CR}_{4}<80 \%$, maka tingkat konsentrasi sedang, dengan bentuk pasar cenderung oligopoli; (3) $\mathrm{CR}_{4} \leq 50 \%$, maka tingkat konsentrasi rendah, bentuk pasar dapat berupa persaingan monopolistik, dan sedikit oligopoli (Hidayati, 2014).

Sedangkan berdasarkan nilai herfindahl index (HI) maka tingkat kompetisi (persaingan) pasar dapat dikelompokkan: apabila HI $<1.000$ maka tingkat persaingan dikatakan tinggi; apabila HI berada diantara 1.000-1.800 maka tingkat persaingan dikatakan sedang; sedangkan jika $1.800<\mathrm{HI}$ $\leq 10.000$ maka tingkat persaingan dikatakan rendah (Parkin, 2003).

\section{Analisis Daya Saing}

\section{a. Revealed Comparative Advantage (RCA)}

RCA merupakan salah satu metode yang dapat digunakan untuk mengukur keunggulan komparatif komoditas suatu negara di negara tertentu ataupun di pasar global. Dalam metode ini, suatu negara dikatakan memiliki keunggulan komparatif yang tinggi apabila nilai indeks RCA-nya lebih besar dari satu (>1). Rumus umum yang digunakan dalam metode RCA adalah sebagai berikut (Wati, Chang, \& Mustadjab, 2013).

$$
\operatorname{RCA}_{\mathrm{ijt}}=\frac{\mathrm{X}_{\mathrm{ijt}}}{\mathrm{X}_{\mathrm{jt}}} \times \frac{\mathrm{W}_{\mathrm{t}}}{\mathrm{W}_{\mathrm{it}}}
$$

Keterangan:

$X_{\mathrm{ijt}}=$ Nilai ekspor udang beku oleh negara $\mathrm{j}$ pada tahun $\mathrm{t}$ (US\$)

$\mathrm{X}_{\mathrm{jt}}=$ Nilai total ekspor negara $\mathrm{j}$ pada tahun $\mathrm{t}$ (US\$)

$\mathrm{W}_{\text {it }}=$ Nilai ekpor udang beku dunia pada tahun t (US\$)

$\mathrm{W}_{\mathrm{t}}=$ Nilai total ekspor dunia pada tahun $\mathrm{t}$ (US\$)

$\mathrm{J}=$ Negara eksportir.

\section{b. Constant Market Share Analysis (CMSA)}

Constant Market Share Analysis (CMSA) adalah analisis yang digunakan untuk mengetahui daya saing ekspor suatu negara. Dengan menggunakan analisis ini, maka akan dapat diketahui faktor apa yang paling berperan dalam peningkatan daya saing ekspor suatu komoditas oleh negara pada periode tertentu (Juarno, 2012). Asumsi dasar yang digunakan dalam CMSA adalah bahwa pangsa pasar suatu negara pengekspor di pasar dunia atau di suatu negara adalah konstan, jika 
terdapat perbedaan pertumbuhan, maka hal ini disebabkan oleh efek komposisi komoditas, efek distribusi pasar, dan efek daya saing (Hadi \& Mardianto, 2004).

Adapun rumus CMSA (Constant Market Share Analysis) versi Leamer dan Stern dalam bentuk pangsa pasar (market share form) adalah sebagai berikut (Fagerberg \& Sollie, 1985):

$$
\begin{aligned}
\Delta \mathrm{A}= & \mathrm{EKK}+\mathrm{EDP}+\mathrm{EDS} \ldots \ldots \ldots \ldots \ldots . . .(6) \\
\mathrm{EKK}= & \sum_{\mathrm{i}} \mathrm{A}_{\mathrm{i}} \Delta \mathrm{B}_{\mathrm{i}} \ldots \ldots \ldots \ldots \ldots \ldots \ldots \ldots \ldots \ldots \ldots \ldots \ldots \ldots \ldots \ldots \ldots \ldots \\
\mathrm{EDP}= & \sum_{\mathrm{i}} \sum_{\mathrm{j}}\left(\mathrm{A}_{\mathrm{ij}} \Delta \mathrm{B}_{\mathrm{ij}} \mathrm{C}_{\mathrm{j}}\right)+\left(\mathrm{A}_{\mathrm{ij}} \mathrm{B}_{\mathrm{ij}} \Delta \mathrm{C}_{\mathrm{j}}\right) \\
& +\left(\mathrm{A}_{\mathrm{ij}} \Delta \mathrm{B}_{\mathrm{ij}} \Delta \mathrm{C}_{\mathrm{j}}\right)-\left(\mathrm{A}_{\mathrm{i}} \Delta \mathrm{B}_{\mathrm{i}}\right) \ldots \ldots(8) \\
\mathrm{EDS}= & \sum_{\mathrm{i}} \sum_{\mathrm{j}}(\Delta \mathrm{A})-\left(\mathrm{A}_{\mathrm{ij}} \Delta \mathrm{B}_{\mathrm{ij}} \mathrm{C}_{\mathrm{j}}\right)+ \\
& \left(\mathrm{A}_{\mathrm{ij}} \mathrm{B}_{\mathrm{ij}} \Delta \mathrm{C}_{\mathrm{j}}\right)-\left(\mathrm{A}_{\mathrm{ij}} \Delta \mathrm{B}_{\mathrm{ij}} \Delta \mathrm{C}_{\mathrm{j}}\right)(9)
\end{aligned}
$$

Pada persamaan (6) diatas, dari sisi kiri yaitu menunjukkan perubahan pangsa pasar total ekspor suatu negara, EKK adalah Efek Komposisi Komoditas, EDP adalah Efek Distribusi Pasar, dan EDS adalah Efek Daya Saing. Dimana:

$$
\begin{array}{ll}
\mathrm{A}=\mathrm{E}_{\mathrm{t}} / \mathrm{W}_{\mathrm{t}}, & \mathrm{A}_{\mathrm{i}}=\mathrm{E}_{\mathrm{i}(\mathrm{t})} / \mathrm{W}_{\mathrm{i}(\mathrm{t})} \\
\mathrm{A}_{\mathrm{ij}}=\mathrm{E}_{\mathrm{ij}(\mathrm{t})} / \mathrm{W}_{\mathrm{ij}(\mathrm{t})}, & \mathrm{B}_{\mathrm{i}}=\mathrm{E}_{\mathrm{i}(\mathrm{t})} / \mathrm{W}_{(\mathrm{t})} \\
\mathrm{B}_{\mathrm{ij}}=\mathrm{E}_{\mathrm{ij}(\mathrm{t})} / \mathrm{W}_{\mathrm{j}(\mathrm{t})}, & \mathrm{C}_{\mathrm{j}}=\mathrm{W}_{\mathrm{j}(\mathrm{t})} / \mathrm{W}_{(\mathrm{t})}
\end{array}
$$

Keterangan:

$\mathrm{E}_{\mathrm{t}} \quad=$ Nilai total ekspor suatu negara ke dunia (US\$)

$\mathrm{E}_{\mathrm{i}(\mathrm{t})}=$ Nilai ekspor udang beku suatu negara ke dunia pada tahun $\mathrm{t}$ (US\$)

$E_{i j(t)}=$ Nilai ekspor udang beku suatu negara ke negara $\mathrm{j}$ pada tahun $\mathrm{t}$ (US\$)

$\mathrm{W}_{\mathrm{t}}=$ Nilai total ekspor dunia pada tahun $\mathrm{t}$ (US\$)

$\mathrm{W}_{\mathrm{i}(\mathrm{t})}=$ Nilai ekspor udang beku dunia pada tahun t (US\$)

$\mathrm{W}_{\mathrm{j}(\mathrm{t})}=$ Nilai total ekspor dunia ke negara $\mathrm{j}$ pada tahun $\mathrm{t}$ (US\$)

$\mathrm{W}_{\mathrm{ij}(\mathrm{t})}=$ Nilai ekspor udang beku dunia ke negara $\mathrm{j}$ pada tahun $\mathrm{t}$ (US\$)

$\mathrm{J}=$ Negara tujuan ekspor Amerika Serikat

$\mathrm{A}_{\mathrm{t}} \quad=$ Pangsa pasar suatu negara di dunia pada tahun $\mathrm{t}$

$\mathrm{A}_{\mathrm{i}(\mathrm{t})}=$ Pangsa pasar udang beku suatu negara di dunia pada tahun $\mathrm{t}$

$A_{i j(t)}=$ Pangsa pasar udang beku suatu negara di negara $\mathrm{j}$ pada tahun $\mathrm{t}$

$\mathrm{B}_{\mathrm{i}(\mathrm{t})}=$ Pangsa udang beku di dunia pada tahun $\mathrm{t}$
$\mathrm{B}_{\mathrm{ij}(\mathrm{t})}=$ Pangsa udang beku di negara $\mathrm{j}$ pada tahun $\mathrm{t}$

$\mathrm{C}_{\mathrm{j}(\mathrm{t})} \quad=$ Pangsa negara $\mathrm{j}$ di dunia pada tahun $\mathrm{t}$

3. Faktor-faktor yang Mempengaruhi Ekspor Udang Beku Indonesia di Pasar Amerika Serikat

Dalam menganalisis faktor-faktor yang mempengaruhi ekspor udang beku (HS 030613) Indonesia di pasar Amerika Serikat menggunakan analisis regresi berganda dengan metode Ordinary Least Square (OLS). Persamaan ekspor udang beku (HS 030613) Indonesia di Pasar Amerika Serikat dalam penelitian ini dirumuskan sebagai berikut (Juarno, 2012) (Muhardini, 2009):

$$
\begin{aligned}
& \operatorname{LnEx}_{t}=\beta_{0}+\beta_{1} \operatorname{LnProd}_{\mathrm{t}}-\beta_{2} \mathrm{LnP}_{\mathrm{UBt}} \\
& +\beta_{3} \mathrm{LnP}_{\mathrm{UO}_{\mathrm{t}}}+\beta_{4} \mathrm{LnER}_{\mathrm{t}} \\
& +\beta_{5} \mathrm{LnY}_{\mathrm{USA}}+\beta_{6} \mathrm{LnD}_{\mathrm{USA} t} \\
& -\beta_{7} \text { D_HACCP }+u
\end{aligned}
$$

Keterangan:

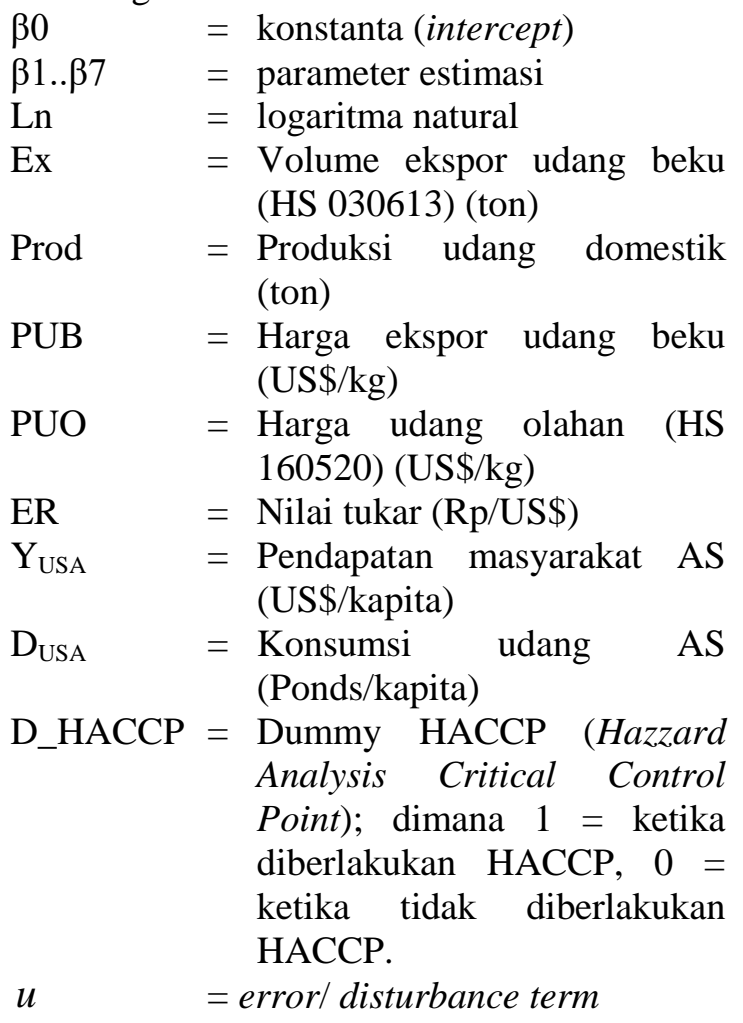

\section{HASIL DAN PEMBAHASAN}

\section{Kinerja Ekspor Ekspor Udang Beku Indonesia di Pasar Amerika Serikat \\ a. Pertumbuhan Ekspor}

Dalam mengukur laju pertumbuhan ekspor udang beku Indonesia di Amerika 
Serikat digunakan rumus laju pertumbuhan. Dari hasil analisis laju pertumbuhan nilai ekspor, diperoleh nilai sebesar $15,54 \%$, yang artinya yaitu rata-rata secara geometris (mengikuti deret hitung) laju pertumbuhan nilai ekspor udang beku Indonesia di Amerika Serikat pada tahun 1989 - 2016 adalah sebesar $15,54 \%$. Angka tersebut lebih besar jika dibandingkan dengan laju rata-rata pertumbuhan volume ekspornya yaitu sebesar $12,77 \%$. Adanya gap (jarak) antara pertumbuhan nilai dengan volume ekspor udang beku ini dapat disebabkan karena perubahan harga, dan perubahan komposisi ragam komoditas udang beku yang diekspor.

Pertumbuhan ekspor udang beku Indonesia ke pasar Amerika Serikat pada periode tahun 1989-2016 yang tertinggi yaitu pada tahun 1996 dengan pertumbuhan nilai ekspor sebesar $90 \%$ dan volume ekspor $82 \%$. Sedangkan penurunan ekspor terendah yaitu pada tahun 1995 dengan pertumbuhan nilai dan volume ekspor masing-masing - $48 \%$ dan 53\%. Pertumbuhan nilai ekspor udang beku Indonesia ke Amerika Serikat dari tahun 1989 - 2016 dapat dilihat pada Gambar 1.

Pada tahun 2004, nilai dan volume ekspor udang beku Indonesia ke AS meningkat, dengan pertumbuhan masingmasing sebesar $55 \%$ dan $64 \%$. Peningkatan ini salah satunya dapat disebabkan karena pada tahun 2004, udang vannamei sudah mulai diproduksi secara besar-besaran oleh petambak. Hal ini tidak lepas dari peranan pemerintah yang gencar melakukan introduksi udang vannamei kepada masyarakat karena tidak hanya dari segi teknis budidayanya yang lebih mudah dibandingkan udang windu, namun juga karena udang yang memiliki nama latin Litopenaeus vanname ini lebih diminati oleh Amerika Serikat dan Jepang.

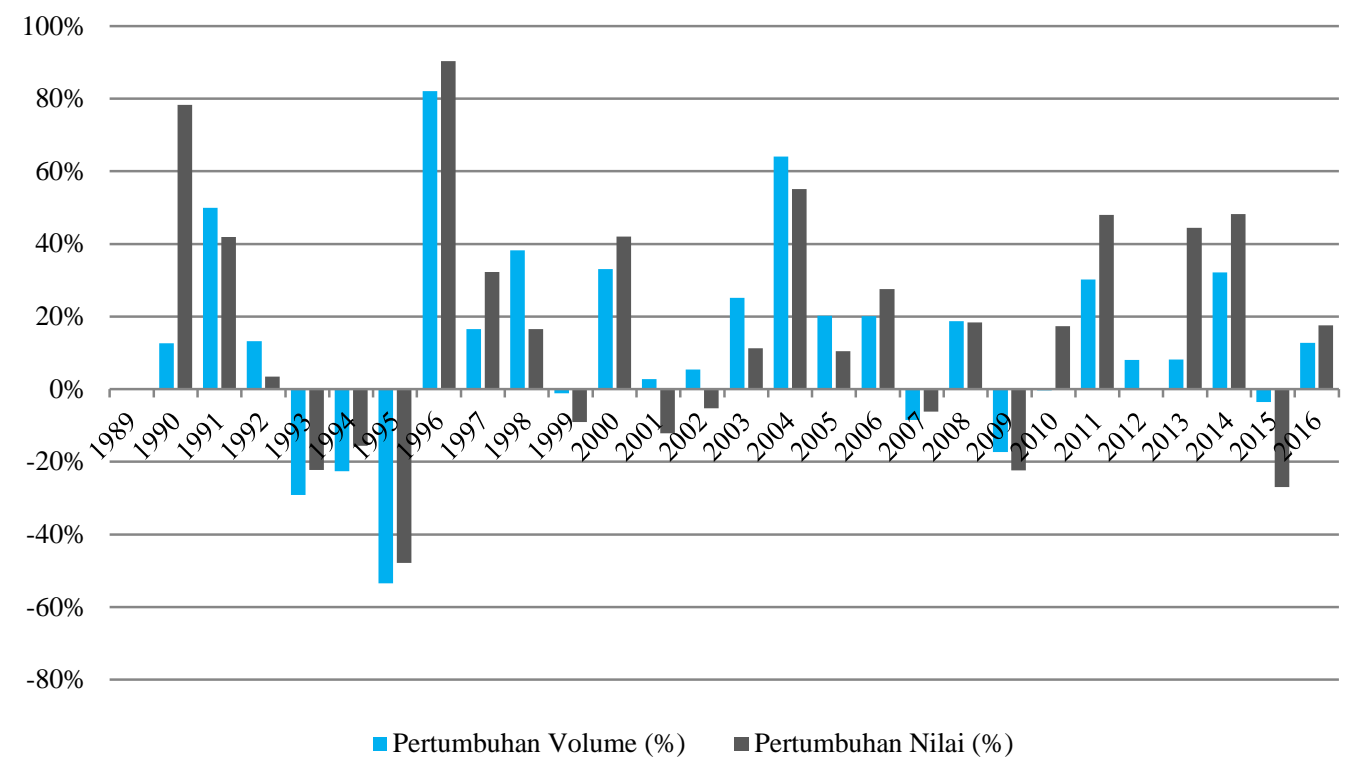

Gambar 1. Pertumbuhan volume dan nilai ekspor udang beku Indonesia di pasar Amerika Serikat, tahun 1989-2016 (\%).

Sumber: UN Comtrade (2018)

\section{b. Pangsa Pasar}

Pangsa pasar (market share) yang dimaksud dalam penelitian ini adalah bagian yang dikuasai dari keseluruhan nilai ekspor udang beku dalam pasar Amerika Serikat dalam periode tahun tertentu, yang digambarkan dalam bentuk persentase $(\%)$.

Adapun hasil dari analisis pangsa pasar dengan menggunakan metode Concentration Ratio $\left(\mathrm{CR}_{4}\right)$ \& Herfindahl Index (HI) dapat dilihat pada Tabel 1. Dari hasil analisis CR4 \& HI diperoleh 4 negara eksportir utama udang beku (HS 030613) di pasar Amerika Serikat pada periode tahun 2007 - 2016 yaitu adalah India, Thailand, Indonesia, dan Ekuador yang memiliki ratarata pangsa pasar masing-masing yaitu $18,25 \%, 16,45 \%, 15,20 \%, 13,75 \%$. Hal ini menunjukkan bahwa pangsa pasar Indonesia menempati posisi ke tiga tertinggi setelah India dan Thailand. Nilai rata-rata CR4 diperoleh yaitu $63,66 \%$, yang berarti struktur 
pasar yang terjadi dalam pasar ekspor udang beku di Amerika Serikat adalah cenderung oligopoli dengan tingkat konsentrasi sedang. Sedangkan nilai rata-rata $\mathrm{HI}$ diperoleh sebesar
1.471 , artinya kompetisi yang terjadi diantara seluruh negara eksportir udang beku di pasar AS berada pada tingkatan sedang.

Tabel 1. Pangsa pasar 4 negara eksportir utama udang beku di pasar Amerika Serikat dengan analisis $\mathrm{HI} \& \mathrm{CR}_{4}$, tahun 2007-2016.

\begin{tabular}{|c|c|c|c|c|c|c|c|c|}
\hline \multirow{2}{*}{ Tahun } & \multicolumn{4}{|c|}{ Pangsa pasar (\%) } & \multirow{2}{*}{$\mathrm{CR}_{4}$} & \multirow{2}{*}{$\mathrm{HI}$} & \multirow{2}{*}{$\begin{array}{c}\text { Tingkat } \\
\text { Konsentrasi }\end{array}$} & \multirow{2}{*}{$\begin{array}{r}\text { Tingkat } \\
\text { Kompetis }\end{array}$} \\
\hline & Indonesia & India & Thailand & Ekuador & & & & \\
\hline 2007 & 10,90 & 6,51 & 20,14 & 9,75 & 47,30 & 1.206 & Rendah & Sedang \\
\hline 2008 & 13,25 & 5,36 & 24,15 & 11,12 & 53,87 & 1.347 & Sedang & Sedang \\
\hline 2009 & 11,16 & 6,55 & 25,47 & 12,01 & 55,19 & 1.335 & Sedang & Sedang \\
\hline 2010 & 10,45 & 10,46 & 25,08 & 11,78 & 57,77 & 1.262 & Sedang & Sedang \\
\hline 2011 & 13,72 & 15,01 & 20,10 & 14,44 & 63,27 & 1.264 & Sedang & Sedang \\
\hline 2012 & 15,66 & 19,53 & 16,81 & 17,41 & 69,42 & 1.376 & Sedang & Sedang \\
\hline 2013 & 17,32 & 27,52 & 9,45 & 16,16 & 70,45 & 1.607 & Sedang & Sedang \\
\hline 2014 & 20,26 & 27,59 & 6,42 & 16,46 & 70,74 & 1.679 & Sedang & Sedang \\
\hline 2015 & 19,03 & 30,82 & 6,76 & 15,26 & 71,87 & 1.740 & Sedang & Sedang \\
\hline 2016 & 20,28 & 33,15 & 10,14 & 13,10 & 76,67 & 1.893 & Sedang & Rendah \\
\hline Rerata & 15,21 & 18,26 & 16,46 & 13,75 & 63,69 & 1.471 & Sedang & Sedang \\
\hline
\end{tabular}

Pada Tahun 2011 hingga 2016 nilai Herfindahl Index cenderung mengalami peningkatan dari 1.264 menjadi 1.893 , hal ini menunjukkan semakin timpangannya penguasaan pangsa pasar udang beku di Amerika Serikat yang mana lebih terkonsentrasi kepada beberapa negara eksportir seperti India dan Indonesia. Pemusatan penguasaan pangsa pasar tersebut ditunjukkan dari perubahan pangsa pasar India pada Tahun 2011-2016 dari 15,01\% menjadi $33,15 \%$, dan pangsa pasar Indonesia dari 13,72\% menjadi 20,28\%.

Pada tahun 2013, pangsa pasar Thailand mengalami penurunan drastis dari $16,81 \%$ ke $9,45 \%$, dan terus mengalami penurunan hingga tahun 2015, dan menyentuh titik terendahnya pada tahun 2014 dengan pangsa pasar sebesar $6,42 \%$. Hal ini disebabkan munculnya wabah penyakit udang Early Mortality Syndrome (ESM) pada tahun 2012, yang menyebabkan kematian pada banyak udang di Thailand. Penyakit ini juga merambah ke berbagai negara seperti China (2009), Vietnam (2010), Malaysia (2010), sampai dengan perbatasan Kamboja (2013). Akibat penyakit ini volume produksi budidaya udang di Thailand dan Vietnam mengalami penurunan yang signifikan (BPS, 2016).

Pangsa pasar Indonesia pada tahun 2009-2010 terus mengalami penurunan, dan mencapai titik terendah selama tahun 2007 2016 dengan pangsa pasar $10,45 \%$ pada tahun 2010. Hal ini disebabkan karena anjloknya produksi udang di berbagai sentra produksi seperti Jawa Barat, Jawa Timur, Lampung, dan lain-lain, karena ada wabah penyakit White Spot Syndrome Virus (WSSV), Taura Syndrome Virus (TSV), dan Infectious Myo Necrosis Virus (IMNV) yang menyerang di berbagai tambak udang di daerah tersebut pada tahun 2009-2010.

Pangsa pasar Indonesia mulai meningkat pada tahun 2011 sebesar 13,72\%, hal ini dipicu karena adanya pengenaan Countervailing Duty (CVD) atau bea penyeimbang oleh Amerika Serikat terhadap komoditas udang beku dari Negara China, Vietnam, Ekuador, India, dan Malaysia karena terindikasi memberikan subsidi ekspor. Hal ini membuat komoditas ekspor Indonesia lebih diminati karena harganya lebih kompetitif, sehingga peluang untuk meningkatkan pangsa pasar semakin besar. Dan ini dibuktikan dengan nilai ekspor udang beku Indonesia ke AS yang lebih tinggi dibandingkan dengan nilai ekspor ke Jepang, yang sebelumnya merupakan pasar tujuan ekspor hasil perikanan Indonesia sejak tahun 1989 hingga 2010

\section{Daya Saing Udang Beku Indonesia di Pasar Amerika Serikat}

\section{a. Revealed Comparative Advantage (RCA)}

Analisis daya saing menggunakan metode Revealed Comparative Advantage (RCA) digunakan untuk mengukur keunggulan komparatif (comparative advantage) suatu negara. Suatu negara dikatakan berdaya saing apabila indeks RCA- 
nya $>1$, namun dalam praktiknya, sebagai bahan pertimbangan untuk membuat keputusan hal ini kurang memberikan makna, sehingga perlu dilakukan perbandingan (komparasi) antara indeks RCA satu dengan yang lain. Adapun hasil analisis RCA Indonesia pada tahun 2007-2016 dapat dilihat pada Tabel 2.

Tabel 2. Indeks RCA India, Indonesia, Thailand, dan Ekuador dalam ekspor udang beku di pasar Amerika Serikat, tahun $2007-2016$.

\begin{tabular}{ccccc}
\hline \multirow{2}{*}{ Tahun } & \multicolumn{3}{c}{ Indeks RCA } & Ekuador \\
\cline { 2 - 5 } & Indonesia & India & Thailand & 29,14 \\
2007 & 16,73 & 5,78 & 18,59 & 25,03 \\
2008 & 19,24 & 4,76 & 22,82 & 36,88 \\
2009 & 14,56 & 4,87 & 21,69 & 33,93 \\
2010 & 12,78 & 7,76 & 21,70 & 29,61 \\
2011 & 16,59 & 9,09 & 18,31 & 33,64 \\
2012 & 21,64 & 10,82 & 15,18 & 30,11 \\
2013 & 22,82 & 13,61 & 8,51 & 31,85 \\
2014 & 26,59 & 14,05 & 5,82 & 44,19 \\
2015 & 24,47 & 15,99 & 5,96 & 49,23 \\
2016 & 25,63 & 16,13 & 8,50 & 34,36 \\
\hline Rata-rata & 20,11 & 10,29 & 14,71 & \\
\hline
\end{tabular}

Pada Tabel 2, dapat dilihat bahwa ke empat negara eksportir (India, Indonesia, Thailand, dan Ekuador) pada periode tahun 2007-2010 memiliki rata-rata indeks RCA diatas satu (>1) yang artinya berdaya saing. Ekuador memiliki keunggulan komparatif tertinggi dibandingkan yang lain, dengan ratarata indeks RCA yaitu 34,36, sedangkan Indonesia menempati posisi kedua dengan rata-rata indeks RCA 20,11, yang disusul oleh Thailand $(14,71)$ dan India $(10,29)$. Tingginya indeks RCA Negara Ekuador, dapat dijelaskan karena kontribusi ekspor udang beku terhadap total ekspor negara tersebut ke Amerika Serikat lebih besar yaitu sebesar 6,15\%, dibandingkan dengan Indonesia (3,88\%), India $(2,38 \%)$, dan Thailand $(2,34 \%)$ (UN Comtrade, 2018).

Indeks RCA Indonesia selama tahun 2007-2016 berfluktuasi, dengan angka terendah yaitu pada tahun 2010 sebesar 12,78, dan angka tertinggi yaitu pada tahun 2014 sebesar 26,59. Pada 2011-2014, indeks RCA Indonesia cenderung mengalami peningkatan, hal ini sekaligus mengindikasi adanya pergeseran tujuan ekspor udang beku Indonesia secara geografis yang mulai terkonsentrasi ke pasar Amerika Serikat dari yang sebelumnya adalah Jepang (1989 2010). Peningkatan keunggulan komparatif udang beku Indonesia di Amerika Serikat tersebut tidak lepas dari adanya program industrialisasi udang oleh pemerintah melalui revitalisasi tambak baru (Tahun 2012); mewabahnya penyakit Early Mortality Syndrome (EMS) yang mengancam produsen di berbagai negara di ASEAN; serta pengenaan Countervailing Duty (CVD) oleh Otoritas AS kepada China, Vietnam, Ekuador, India, dan Malaysia (Tahun 2011).

\section{b. Constant Market Share Analysis (CMSA) \\ Constant Market Share Analysis}

(CMSA) merupakan suatu metode untuk mengukur daya saing komoditas suatu negara berdasarkan keunggulan kompetitif (competitive advantages). Analisis ini digunakan untuk melihat komponenkomponen yang menyumbang pertumbuhan pangsa pasar, yang dibagi atas tiga efek yaitu: Efek Komposisi Komoditas (EKK), Efek Distribusi Pasar (EDP), dan Efek Daya Siang (EDS). Hasil dekomposisi CMSA komoditas udang beku Indonesia, India, Thailand, Vietnam tahun 2007-2016 disajikan pada Tabel 3.

Pada Tabel 3, hasil dari analisis CMSA pada tahun 2007-2016 diperoleh ratarata pertumbuhan aktual pangsa pasar ekspor Indonesia adalah sebesar $0,77 \times 10^{-4}$, yang artinya terjadi peningkatan pangsa pasar aktual, dimana sebagian besar dipengaruhi positif oleh Efek Daya Saing (EDS) sebesar 98,74\%. Efek Komposisi Komoditas (EKK) bertanda positif yaitu sebesar $0,01972 \times 10^{-4}$ $(2,56 \%)$, ini menujukkan bahwa ekspor udang beku Indonesia secara agregat ternyata mengalami pertumbuhan ke arah positif. Sementara itu, Efek Distribusi Pasar (EDP) bertanda negatif yaitu sebesar $-0,01 \times 10^{-4}(-$ $1,30 \%$ ), yang artinya pasar Amerika Serikat 
memiliki pertumbuhan impor yang relatif lambat dibandingkan dengan trend pertumbuhan impor global. Hal ini juga ditunjukkan dengan pertumbuhan pangsa Efek
Distribusi Pasar (EDP) Negara India, Thailand, dan Ekuador yang juga bertanda negatif.

Tabel 3. Hasil analisis dekomposisi CMSA terhadap perubahan pangsa pasar Indonesia, India, Thailand, dan Vietnam, tahun 2007-2016.

\begin{tabular}{ccrrrr}
\hline \multirow{2}{*}{ Negara } & Satuan & Perubahan Aktual & \multicolumn{3}{c}{ Dekomposisi } \\
\cline { 4 - 6 } Indonesia & $\left(\times 10^{-4}\right)$ & 0,76885 & 0,01972 & $-0,01000$ & \multicolumn{1}{c}{ EDS } \\
& $\%$ & 100.00 & 2,56 & $-1,30$ & 98,74 \\
\multirow{2}{*}{ India } & $\left(\times 10^{-4}\right)$ & 6,47771 & 0,04631 & $-0,02791$ & 6,45931 \\
& $\%$ & 100,00 & 0,71 & $-0,43$ & 99,72 \\
\multirow{2}{*}{ Thailand } & $\left(\times 10^{-4}\right)$ & 2,68994 & 0,01589 & $-0,01603$ & 2,69008 \\
& $\%$ & 100,00 & 0,59 & $-0,60$ & 100,01 \\
\multirow{2}{*}{ Ekuador } & $\left(\times 10^{-4}\right)$ & 0,00429 & 0,03654 & $-0,02720$ & $-0,00505$ \\
& $\%$ & 100,00 & 852,67 & $-634,77$ & $-117,89$ \\
\hline
\end{tabular}

Tingginya konsentrasi ekspor udang beku ke Amerika Serikat, akan mengancam kinerja ekspor Indonesia apabila negara tersebut sewaktu-waktu mengalami gangguan ataupun melakukan kebijakan proteksi. Delgado dkk, (2003) dalam Juarno (2012) menambahkan bahwa perlu adanya diversifikasi tujuan pasar, karena kecenderungan perdagangan udang global akan bergeser dari South (negara berkembang) ke North (negara maju) menjadi South (negara berkembang) ke South (negara berkembang). Hal ini dikarenakan adanya kecenderungan peningkatan yang pesat akan konsumsi komoditas hasil perikanan seperti udang di berbagai negara berkembang, seiring dengan peningkatan pendapatan masyarakat, populasi, dan urbanisasi (Delgado, dkk, 2003).

Hasil analisis CMSA pada Tabel 3, menunjukkan bahwa pertumbuhan secara positif pangsa pasar ekspor Indonesia dengan negara pesaing yaitu India, dan Thailand sebagian besar disebabkan oleh Efek Daya Saing (Competitiveness Effect) yang masingmasing bernilai sebesar $0,75913 \times 10^{-4}$, $6,45931 \times 10^{-4}$, dan $2,69008 \times 10^{-4}$, hal ini sekaligus menunjukkan bahwa daya saing komoditas udang beku Indonesia di pasar AS berada pada peringkat ke tiga, setelah India, dan Thailand. Sedangkan pertumbuhan pangsa pasar Negara Ekuador sebagian besar secara positif disebabkan oleh Efek Komposisi Komoditas (Commodity Composition Effect) yang menyumbang sebesar $852,67 \%$, dan
Efek Daya Saing justru bertanda negatif yaitu sebesar $-0,00505 \times 10^{-4}(-117,89 \%)$.

\section{Faktor-faktor yang Mempengaruhi Ekspor Udang Beku Indonesia di Pasar Amerika Serikat}

Pada Penelitian ini faktor-faktor yang mempengaruhi ekspor udang beku (HS 030613) Indonesia di pasar Amerika Serikat (EX) yaitu produksi domestik (Prod), harga udang beku $\left(\mathrm{P}_{\mathrm{UB}}\right)$, harga udang olahan $\left(\mathrm{P}_{\mathrm{UO}}\right)$, nilai tukar rill (RER), pendapatan masyarakat AS ( $\left.\mathrm{Y}_{\text {USA }}\right)$, Konsumsi udang AS $\left(\mathrm{C}_{\text {USA }}\right)$, dan kebijakan HACCP (D_HACCP). Hasil dari estimasi tersebut dapat dilihat pada Tabel 4.

Berdasarkan hasil analisis regresi berganda dengan metode OLS (Ordinary Least Squared) yang ditampilkan secara ringkas pada Tabel 4, diperoleh probability $\mathrm{F}$ sebesar 0,000 $(<0,05)$, berarti H0 ditolak yang artinya variabel independent (produksi domestik, harga udang beku, harga udang olahan, nilai tukar rill, pendapatan masyarakat AS, konsumsi udang AS, dan dummy HACCP) secara simultan (bersama-sama) berpengaruh nyata (signifikan) terhadap ekspor udang beku Indonesia di pasar AS. Adjusted R-Squared (Adj $\mathrm{R}^{2}$ ) diperoleh sebesar 0,902 $(90,20 \%)$, yang artinya sebesar $90,20 \%$ variasi variabel dependent (ekspor udang beku) dapat dijelaskan oleh variabel independent, sedangkan sisanya sebesar $9,80 \%$ dapat dijelaskan oleh variabel di luar model, seperti kebijakan tarif dan kebijakan non tarif lainnya. 
Tabel 4. Hasil analisis faktor-faktor yang mempengaruhi ekspor udang beku Indonesia di pasar Amerika Serikat.

\begin{tabular}{|c|c|c|c|c|c|}
\hline No & Model & Coefficients & $\mathrm{T}$ & Probability & VIF \\
\hline 1 & Constant & $-21,030$ & $-4,174$ & 0,001 & \\
\hline 2 & LN Prod & 2,020 & 7,078 & $0,000^{*}$ & 3,722 \\
\hline 3 & $\mathrm{LN} \mathrm{P}_{\mathrm{UB}}$ & $-1,140$ & $-3,626$ & $0,002 *$ & 1,472 \\
\hline 4 & $\mathrm{LN} \mathrm{P}_{\mathrm{UO}}$ & 0,445 & 2,242 & $0,037 *$ & 2,389 \\
\hline 5 & LN RER & 0,694 & 2,111 & $0,048^{*}$ & 2,117 \\
\hline 6 & LN Y $\mathrm{Y}_{\text {USA }}$ & 0,916 & 0,225 & 0,824 & 1,354 \\
\hline 7 & $\mathrm{LN} \mathrm{C}_{\text {USA }}$ & 1,736 & 1,449 & 0,164 & 1,368 \\
\hline 8 & D_HACCP & $-0,215$ & $-0,903$ & 0,378 & 3,346 \\
\hline \multicolumn{2}{|c|}{ F-Statistic } & 35,346 & & & \\
\hline \multicolumn{2}{|c|}{ Probability F } & $0,000^{*}$ & & & \\
\hline \multicolumn{2}{|c|}{ Adjust R-Squared } & 0,902 & & & \\
\hline \multicolumn{2}{|c|}{ Durbin-Watson (D-W) } & 1,900 & & & \\
\hline
\end{tabular}

\section{Produksi Domestik (Prod)}

Koefisien regresi variabel produksi domestik (Prod) diperoleh yaitu sebesar 2,02 (berhubungan positif), artinya peningkatan produksi udang domestik sebesar $1 \%$ akan menyebabkan peningkatan terhadap ekspor udang beku Indonesia ke Amerika Serikat sebesar 2,02\% (cateris paribus), dan begitu juga sebaliknya. Hasil uji t (parsial) diperoleh nilai probabilitas yaitu sebesar $0,000(<0,05)$, maka H0 ditolak, artinya variabel produksi domestik (Prod) secara parsial (individu) berpengaruh nyata (signifikan) terhadap ekspor udang beku Indonesia di pasar Amerika Serikat. Hal ini sejalan dengan penelitian yang dilakukan oleh Widyastutik \& Ashiqin (2011), yang menyatakan bahwa produksi domestik berpengaruh nyata (signifikan) dan positif terhadap ekspor suatu komoditas ke pasar tujuan.

\section{Harga Udang beku ( $\left.P_{\text {UB (t-1) }}\right)$}

Harga udang beku dalam penelitian ini menggunakan harga udang beku (HS 030613) yang diekspor Indonesia dengan skema FOB (Free on Board) ke AS pada periode tahun sebelumnya (t-1), sehingga perubahan harga ekspor udang beku hanya akan berpengaruh terhadap permintaan ekspor AS dan penawaran ekspor Indonesia. Koefisien regresi variabel harga udang beku $\left(\mathrm{P}_{\mathrm{UB}}\right)$ diperoleh yaitu sebesar $-1,14$ (berhubungan negatif), artinya peningkatan harga ekspor udang beku sebesar $1 \%$ akan menyebabkan penurunan terhadap ekspor udang beku Indonesia ke Amerika Serikat sebesar $1,14 \%$ (cateris paribus), dan begitu juga sebaliknya. Hasil uji t (parsial) diperoleh nilai probabilitas yaitu sebesar $0,002(<0,05)$, maka H0 ditolak, artinya variabel harga udang beku (PUB) secara parsial (individu) berpengaruh nyata (signifikan) terhadap ekspor udang beku Indonesia di pasar Amerika Serikat.

Hal ini sejalan dengan penelitian yang dilakukan oleh Wiranthi \& Mubarok (2017), bahwa harga ekspor berpengaruh negatif dan nyata (signifikan) terhadap volume ekspor komoditas itu sendiri ke negara tujuan. Penurunan harga ekspor komoditas membuat permintaan terhadap ekspor dari negara tujuan menjadi meningkat, karena harga lebih kompetitif dibandingkan komoditas sejenis dari negara lain.

\section{Harga Udang Olahan $\left(\mathbf{P}_{\mathrm{UO}(\mathrm{t}-1)}\right)$}

Udang olahan (HS 160520) adalah udang olahan siap saji (preserved) yang disajikan dalam kemasan kedap udara (in airtight containers) maupun kemasan tidak kedap udara (in not airtight containers). Udang olahan merupakan bentuk produk turunan (down stream) dari udang beku, yang bersifat saling menggantikan. Koefisien regresi variabel harga udang olahan $\left(\mathrm{P}_{\mathrm{UO}}\right)$ diperoleh yaitu sebesar 0,445 (berhubungan positif), artinya peningkatan harga ekspor udang olahan sebesar $1 \%$ pada tahun sebelumnya (t-1) akan menyebabkan peningkatan terhadap ekspor udang beku Indonesia ke Amerika Serikat sebesar 0,445\% (cateris paribus), dan begitu juga sebaliknya. Tanda koefisien regresi yang positif (+), menunjukkan bahwa udang olahan merupakan komoditas subtitusi (pengganti) udang beku, karena secara teoritis kenaikan harga komoditas subtitusi menyebabkan peningkatan permintaan akan komoditas lain yang bekaitan. Hasil uji t (parsial) diperoleh nilai probabilitas yaitu sebesar $0,037(<0,05)$, 
maka H0 ditolak, artinya variabel harga udang olahan $\left(\mathrm{P}_{\mathrm{UO}}\right)$ secara parsial (individu) berpengaruh nyata (signifikan) terhadap ekspor udang beku Indonesia di pasar Amerika Serikat. Hal ini juga sejalan dengan penelitian yang dilakukan oleh Yudiarosa (2009), yang menyatakan bahwa komoditas subtitusi berpengaruh positif terhadap permintaan ekspor suatu komoditas oleh negara tujuan eskpor.

\section{Nilai Tukar Rill (RER)}

Koefisien regresi variabel nilai tukar rill (RER) diperoleh yaitu sebesar 0,694 (berhubungan positif), artinya peningkatan (apresiasi) nilai tukar rill dolar AS terhadap rupiah sebesar $1 \%$ akan menyebabkan peningkatan terhadap ekspor udang beku Indonesia ke Amerika Serikat sebesar 0,694\% (cateris paribus), dan begitu juga sebaliknya. Hasil uji t (parsial) diperoleh nilai probabilitas yaitu sebesar $0,048(<0,05)$, maka H0 ditolak, artinya variabel nilai tukar rill (RER) secara parsial (individu) berpengaruh nyata (signifikan) terhadap ekspor udang beku Indonesia di pasar Amerika Serikat. Hal ini sejalan dengan penelitian yang dilakukan oleh Kanaya \& Firdaus (2014), yang menyatakan bahwa nilai tukar berhubungan positif dan signifikan terhadap ekspor suatu komoditas, karena apabila nilai tukar rill meningkat (mata uang negara eksportir terdepresiasi) maka harga komoditas dari negara eksportir lebih murah dibandingkan harga komoditas serupa di negara tujuan ekspor, sehingga permintaan akan ekspor meningkat.

\section{Pendapatan Masyarakat Amerika Serikat} $\left(\mathbf{Y}_{\text {USA }}\right)$

Koefisien regresi pendapatan masyarakat AS (YUSA) diperoleh yaitu sebesar 0,916 (berhubungan positif), artinya peningkatan pendapatan masyarakat AS sebesar $1 \%$ akan menyebabkan peningkatan terhadap ekspor udang beku Indonesia ke Amerika Serikat sebesar $0,916 \%$ (cateris paribus), dan begitu juga sebaliknya. Hasil uji $\mathrm{t}$ (parsial) diperoleh nilai probabilitas yaitu sebesar 0,824 $(>0,05)$, maka H0 diterima, artinya variabel pendapatan masyarakat AS (YUSA) secara parsial (individu) tidak berpengaruh nyata (signifikan) terhadap ekspor udang beku Indonesia di pasar Amerika Serikat. Meningkatnya pendapatan masyarakat Amerika Serikat dapat diartikan sebagai peningkatan daya beli, yang sertamerta akan meningkatkan jumlah permintaan masyarakat terhadap komoditas normal (normal goods) termasuk salah satunya adalah permintaan ekspor udang beku Indonesia. Hal ini sejalan dengan penelitian yang dilakukan oleh Iskandar, Jauhari, Mulyana, \& Dewata (2012), yang menyatakan bahwa pendapatan masyarakat (GDP) negara tujuan berpengaruh positif namun tidak signifikan terhadap ekspor suatu komoditas ke negara tujuan.

\section{Konsumsi Udang Amerika Serikat $\left(\mathbf{C}_{\text {USA }}\right)$} Koefisien regresi variabel konsumsi udang AS $\left(\mathrm{C}_{\mathrm{USA}}\right)$ diperoleh yaitu sebesar 1,736 (berhubungan positif), artinya peningkatan harga ekspor udang olahan sebesar $1 \%$ akan menyebabkan peningkatan terhadap ekspor udang beku Indonesia ke Amerika Serikat sebesar $1,736 \%$ (cateris paribus), dan begitu juga sebaliknya. Hal ini tidak lepas dari keyataan bahwa sebagian besar kebutuhan udang Amerika Serikat dipenuhi melalui impor, dan sekitar $80 \%$ nya diimpor dalam bentuk beku, yang mana sekitar 20,36\% impor udang beku tersebut (pada tahun 2016) berasal dari Indonesia. Oleh karena itu, semakin tinggi konsumsi masyarakat AS terhadap udang, maka akan semakin tinggi pula permintaan akan ekspor udang beku Indonesia. Hasil uji t (parsial) diperoleh nilai probabilitas yaitu sebesar 0,164 $(>0,05)$, maka H0 diterima, artinya variabel konsumsi udang AS (CUSA) secara parsial (individu) tidak berpengaruh nyata (signifikan) terhadap ekspor udang beku Indonesia di pasar Amerika Serikat.

\section{Kebijakan HACCP (Hazzard Analysis Critical Control Point) \\ HACCP (Hazzard Analysis Critical}

Control Point) adalah suatu sistem manajemen pengendalian dan pengawasan mutu terpadu yang berorientasi pada prinsip pendeteksian dan pencegahan secara dini (preventive measure). Koefisien regresi kebijakan HACCP (Hazzard Analysis Critical Control Point) diperoleh yaitu sebesar -0,215 (berhubungan negatif), artinya ekspor udang beku Indonesia ke Amerika Serikat pada saat pemberlakuan kebijakan HACCP (tahun 1996-2016) mengalami penurunan sebesar $0,215 \%$ (cateris paribus). Hasil uji t (parsial) diperoleh nilai probabilitas yaitu sebesar 0,378 $(<0,05)$, maka H0 diterima, artinya variabel kebijakan HACCP secara parsial (individu) 
tidak berpengaruh nyata (signifikan) terhadap ekspor udang beku Indonesia di pasar Amerika Serikat.

Tanda negatif (-) pada variabel dummy HACCP dapat dijelaskan karena kebijakan HACCP membuat standar tuntutan terhadap jaminan mutu semakin tinggi, sehingga menambah beban kerja produsen dan produsen yang tidak dapat memenuhi berbagai standar tersebut konsekuensinya adalah produknya akan ditolak masuk ke Amerika Serikat. Menurut Putro (2008), tuntutan seperti ini seiring dengan arah globalisasi perdagangan, yang terus mengedepankan pentingnya aspek mutu dan keamanan pangan, sehingga perbaikan sistem pembinaan mutu sangat diperlukan untuk meningkatkan daya saing dan akses pasar. Tidak signifikannya penerapan kebijakan HACCP dapat dijelaskan karena penerapan kebijakan tersebut hanya membebani produsen pada tahun-tahun awal sejak kebijakan itu diberlakukan. Hasil penelitian Juarno (2012) menunjukkan bahwa penerapan sistem HACCP behubungan negatif dan signifikan terhadap ekspor udang beku Indonesia di Pasar Amerika Serikat.

\section{KESIMPULAN DAN SARAN}

\section{Kesimpulan}

Dari hasil dan pembahasan yang telah dikemukakan sebelumnya, adapun kesimpulan dapat ditarik adalah sebagai berikut:

1. Kinerja ekspor udang beku Indonesia di pasar Amerika Serikat dilihat dari rata-rata laju pertumbuhan nilai ekspor adalah sebesar 11,49\% pada tahun 1989-2016, dengan laju pertumbuhan tertinggi pada tahun 1996 sebesar 90\%; rata-rata pada tahun 2007-2016 nilai $\mathrm{CR}_{4}$ \& $\mathrm{HI}$ diperoleh masing-masing 63,69\% \& 1.471, artinya konsentrasi dan kompetisi pasar berada pada tingkat sedang. Berdasarkan pangsa pasar, Indonesia menempati posisi ke tiga tertinggi setelah India dan Thailand dengan rata-rata pangsa pasar sebesar $15,21 \%$.

2. Daya saing ekspor udang beku diperoleh: (a) Berdasarkan keunggulan komparatif, Indonesia menempati posisi ke dua (diantara 4 negara eksportir terbesar: India, Indonesia, Thailand, dan Ekuador) dengan rata-rata indeks RCA sebesar 20,11 pada tahun 2007-2016. (b) Berdasarkan keunggulan kompetitif dengan metode CMSA diperoleh bahwa pada tahun 2007-
2016 sebagian besar perubahan pangsa pasar ekspor dipengaruhi oleh efek daya saing udang beku sebesar $0,75913 \times 10^{-4}$ $(98,74 \%)$, dari angka tersebut, Indonesia menempati posisi ke tiga dengan keunggulan kompetitifnya setelah India, dan Thailand.

3. Dengan taraf signifikansi $(\alpha)$ sebesar 0,05 (5\%), maka diperoleh faktor-faktor yang berpengaruh nyata (signifikan) terhadap ekspor udang beku Indonesia di pasar Amerika Serikat berdasarkan uji t adalah: produksi domestik (+), harga udang beku (), harga udang olahan $(+)$, dan nilai tukar rill (+). Berdasarkan uji $F$, variabel indepent (produksi domestik, harga udang beku, harga udang olahan, nilai tukar rill, perdapatan mayarakat AS, konsumsi udang AS, dan kebijakan HACCP), secara bersama-sama berpengaruh nyata (signifikan). Nilai Adjusted $\mathrm{R}^{2}$ sebesar 0,902 , yang artinya variasi variabel dependent (eskpor udang beku Indonesia) sebesar 90,20\% dapat dijelaskan oleh variabel independent, sedangkan sisanya 9,80\% dapat dijelaskan oleh variabel diluar model, seperti kebijakan tarif (tarif impor \& pajak eskpor) dan kebikaan non tarif lainnya.

\section{Saran}

Berdasarkan kesimpulan yang telah kemukakan sebelumnya, adapun saran yang dapat diberikan adalah:

1. Dengan kinerja dan daya saing ekspor yang udang beku Indonesia di pasar Amerika yang baik dengan posisi yang kuat, maka perlu sekiranya pencapaian ini dipertahankan melalui berbagai skema kebijakan dan kerjasama bilateral.

2. Mengingat besarnya kontribusi udang terhadap ekspor hasil perikanan, maka perlu dilakukan penelitian lebih lanjut mengenai daya saing udang dengan pendekatan dan unit analisis yang berbeda.

\section{DAFTAR PUSTAKA}

Asrol, A., \& Heriyanto, H. (2018). Daya Saing Ekspor Pala Indonesia di Pasar Internasional. Dinamika pertanian, 33(2), 61-70.

BPS (Badan Pusat Statistik). 2016. Statistik Sumber Daya Laut dan Pesisir 2016. Badan Pusat Statistik. Jakarta. 2017. Statistik Sumber Daya Laut dan Pesisir 2017. Badan Pusat Statistik. Jakarta. 
Delgado, C.L., N. Wada, M. W. Rosegrant, S. Meijer, M. Ahmed. 2003. Fish to2020:Supply and Demand in Changing

Global Markets. International Food Policy Research Institute. Washington D.C.

Heriyanto, H. (2018). Indonesian Coconut Competitiveness In International Markets. Asia Proceedings of Social Sciences, 1(3), 46-50.

Iskandar, S., H. Jauhari, A. Mulyana, \& E. Dewata. 2012. Analysis of Determinant Factors Influencing Cinnamon Export and Prices in Indonesia. Proceeding The 13th Malaysia Indonesia Conference on Economics, Management and Accounting (MIICEMA). 955-965.

Juarno, Ono. 2012. Daya Saing dan Strategi Peningkatan Ekspor Udang Indonesia di Pasar Internasional. [Disertasi]. Sekolah Pascasarjana, Institut Pertanian Bogor. Bogor.

Ningsih, V., Wahyuni, N., Suryati, N., Noviyanto, N., \& Heriyanto, H. (2020). Competitiveness Sensitivity of Oil Palm Farming on Suboptimal Land at Musi Rawas Residence. Journal of Applied Agricultural Science and Technology, 4(1), 26-35. https://doi.org/10.32530/ jaast.v4i1.147. https:// kinfopolitani.com/index.php/ JAAST/issue/view/8
Kanaya, I. A., \& Firdaus, M. (2014). Daya saing dan permintaan ekspor produk biofarmaka Indonesia di negara tujuan utama periode 20032012. Jurnal Manajemen \& Agribisnis, 11(3), 183- 198. doi: https://doi.org/10.17358/ jma.11.3.183-198.

Muhardini, Dian. 2009. Determinants of Indonesia's Shrimp Exports: A Cross Country Analysis from Main Indonesia's Shrimp Export Destination in the EU. [Tesis]. International Institute of Social Studies. The Hague.

Putro, B. (2008). Membuat Dendeng Rendah Kolesterol dari Jantung Pisang. Jakarta: AgroMedia Pustaka

Susanti, M. N. 2010. Statistika Deskriptif Induktif. Graha Ilmu. Yogyakarta.

UN Comtrade. 2018. UN Comtrade Database. Dipetik April 26, 2018, dari United Nation Commodity Trade: Https://comtrade.un.org/data.

Wahyudy, H. A., Khairizal, K., \&

Heriyanto, H. (2019).

Perkembangan Ekspor Karet ALam indonesia. Dinamika Pertanian, 34(2), 1-8.

Wati, L. A., W. I. Chang, \& M. M. Mustadjab. 2013. Competitiveness of Indonesian Shrimp Compare with Thailand Shrimp in Export Market. Wacana, 16(1): 24-31.

Wiranthi, P. E., \& F. Mubarok. 2017. Competitiveness and the Factors Affecting Export of the Indonesia Canned Pineapple in the World and the Destination Countries. 2nd International Conference on Sustainable Agriculture and Food Security: A Comprehensive Approach. 339-352. Klowledge E.Yudiarosa, I. 2009. Analisis ekspor ikan tuna indonesia. Jurnal Wacana, 12(1): 116- 134. 